\title{
Australia's Constitutional Rights and the Problem of Interpretive Disagreement
}

\begin{abstract}
This article critically reviews Australia's express and implied constitutional rights. It is suggested that the rights conferred by the Australian Constitution are undermined by continuing disagreement as to their foundations. This disagreement makes the protection of rights under the Australian Constitution especially weak. Although all constitutional rights are subject to disagreement as to their extent, many, if not all, of Australia's constitutional rights are subject to disagreement as to their existence. The article concludes with some observations on the debate over an Australian bill of rights.
\end{abstract}

* Fellow, Research School of Social Sciences, Australian National University. Thanks are due to Peter Cane, Jeffrey Goldsworthy, Graeme Hill, James Stellios, Amelia Simpson, Fiona Wheeler and Leslic Zines for their helpful comments on carlier drafts. The research for this article was funded by the Australian Research Council. 


\section{Introduction}

The rights found in the Australian Constitution are regarded as patchy, inconsistently interpreted and, in the case of 'implied' rights, obscure. ${ }^{1}$ The inadequacy of Australia's constitutional rights is frequently one plank in an argument for an Australian bill of rights. ${ }^{2}$ In this article, I subject Australia's constitutional rights to closer scrutiny. My point is three-fold. First, I seek to broaden the understanding of how rights pervade, or could pervade, Australian constitutional law. Secondly, I re-examine the critique of Australia's constitutional rights. I agree with the view that Australia's constitutional rights are especially weak, but I provide a more precise articulation of the source of that weakness. Finally, I briefly consider the implications of this analysis in deciding whether Australia should adopt a constitutional bill of rights.

I begin, in Part Two, with a brief review of Australia's existing constitutional rights. The analysis extends beyond the express and implied rights that form the backbone of Australia's constitutional rights, to less obvious means of rights protection found in apparently rights-neutral contexts. In this latter section, I show how the High Court can pursue rights protection through the use of rights-sensitive interpretive devices and judicially created rules for the application of constitutional provisions.

In Part Three, I assess the claim that Australia's constitutional rights are an especially weak form of protecting rights. I will argue that a system of rights protection that depends so heavily on the implication of rights, and on the incorporation of rights from extra-constitutional sources and other judicially created rules of constitutional law, is inevitably weak. The source of this weakness lies in the contested nature of constitutional interpretation itself. Because the methods of constitutional interpretation on which Australia's constitutional rights rely are themselves contested, many of these rights are subject to an ongoing disagreement as to their very existence. The doubt that attends the use of these methods is exacerbated when they are used in the context of a written constitution that deals primarily with non-rights concerns and was drafted without much consideration of rights. Arguments based on constitutional text and constitutional history will, therefore, tend to run counter to rights-protective readings of the Constitution.

1 For critiques of the express rights, see Leslie Zines, The IIigh Court and the Constitution $\left(4^{\text {th }}\right.$ ed, 1997) at 410; Hilary Charlesworth, Writing in Rights (2002) at 30-31; George Williams, Human Rights Under the Australian Constitution (1999) at 245; Peter Bailey, Human Rights: Australia in an International Context (1990). With respect to the 'implied rights' see Williams, id at 259 and for a detailed critique of the freedom of political communication see Adrienne Stone, "Rights, Personal Rights and Freedoms: The Nature of the Freedom of Political Communication' (2001) 25 MULR 374; 'Freedom of Political Communication, the Constitution and the Common Law' (1998) 26 Fed LR 219; 'The Limits of Constitutional Text and Structure' (1999) 23 MULR 668.

2 See, for example, Williams, id at 245, 257, 259; Murray Wilcox, An Australian Charter of Rights? (1993) at 194-209, 230-231. 
In many cases, then, Australia's constitutional rights are likely to be accompanied by disagreement about the methods of constitutional interpretation on which they rely. Such rights are peculiarly vulnerable to judicial revision in the short-term. Further, even when a right obtains a degree of acceptance over time, doubts surrounding its recognition will adversely affect its development.

I conclude with some brief reflections on the implications of these conclusions for the Australian bill of rights debate. It follows from my analysis in Part Three that an express bill of rights in the Australian Constitution would put to rest one important area of dispute by providing an unarguable basis for the recognition of constitutional rights. However, I suggest that the settling of that interpretive controversy is not, itself, a reason to adopt a bill of rights because such a reform would, overall, make constitutional adjudication considerably more complex and uncertain.

\section{2. $\quad$ Rights Under the Australian Constitution}

\section{A. Express and Implied Rights}

The Australian Constitution is usually understood to contain express rights and rights implied from constitutional text and structure. Far more controversially, it has also been suggested that the Constitution contains rights implied from fundamental underlying doctrines. ${ }^{3}$ Since these rights have received extensive treatment elsewhere, ${ }^{4}$ I will deal with them only briefly before turning to another constitutional method of protecting rights.

(i) 'Express Rights'

Despite the absence of a comprehensive bill of rights, a number of provisions in the Australian Constitution are often categorised as 'express rights'. The provisions most often placed in this category are s116, which in part prevents the Commonwealth acting to 'establish' a religion or to prohibit its 'free exercise'; 6 s80, which provides for a jury trial when a Commonwealth offence is tried on indictment; s51(xxxi), which qualifies the Commonwealth power to acquire property with a requirement to provide 'just terms'; and s117, which prevents discrimination based on state residence. ${ }^{7}$

3 For a different, but very helpful, account of the 'schema' of constitutional rights see George Winterton, 'Constitutionally Entrenched Common Law Rights' in Charles Sampford \& Kim Preston, Interpreting Constitutions (1996) at 121.

4 See Zines, above $\mathrm{n} 1$ at 373-399, 400-423; Winterton, above $\mathrm{n} 3$.

5 Zines, above $\mathrm{nl}$ at 402-415; Williams, above $\mathrm{nl}$ at 96-128, 129-154.

6 In these two respects, s116 resembles the non-establishment and free exercise clauses of the First Amendment to the United States Constitution. Section 116 also prevents the Commonwealth from 'imposing any religious observance' and provides that 'no religious test shall be required as a qualification for any office or public trust under the Commonwealth'.

7 The list of express rights sometimes also includes $\mathrm{s} 41$, which gives those who qualify as state electors the right to vote in federal elections; s92, which requires that interstate trade and commerce be 'absolutely free'; and s51(xiiiA), which precludes the 'civil conscription' of medical practitioners. 
From a rights perspective, the High Court's interpretation of these provisions has (with the exception of s117) been disappointing. The rights that resemble traditional civil and political rights - such as sections 80 and 116 - have been given very narrow fields of operation, ${ }^{8}$ and criticism of their evisceration is heightened by charges of inconsistency. Commentators have complained of the court's inconsistent preference for plain or literal meaning of constitutional text in some cases and for the framers' intent in others. ${ }^{9}$ The narrowness of the court's approach to these civil and political rights also contrasts unfavorably with those sections that seem to confer 'economic rights' (such as s51(xxxi) and s92), which have been given a relatively wide field of operation. ${ }^{10}$ Though a thoroughgoing reinterpretation of the 'express rights' provisions is often advocated, ${ }^{11}$ that argument has, with one notable exception (the interpretation of s117) ${ }^{12}$ met with little success.

\section{(ii) Implied Rights - Text and Structure}

A second form of constitutional right in the Australian Constitution arises from a method of interpretation known as 'implication from text and structure'. Two wellknown kinds of implied rights in the Australian Constitution provide illustrations - the rights implied from representative and responsible government, and the rights implied from the separation of judicial power.

8 As interpreted by the High Court, s80 does not apply if Parliament provides that an offence is not to be tried on indictment: $R v$ Archdall \& Roskruge (1928) 41 CLR 128. The protection of religion by s116 is readily outweighed by other values: see for example, Adelaide Company of Jehovah's Witnesses Inc v Commonwealth (1943) 67 CLR 116 (holding that s116 did not prohibit laws prohibiting advocacy detrimental to the prosecution of war by the Commonwealth, even if that advocacy is undertaken in pursuit of religious conviction); Attorney-General (Vic); Ex rel Black v Commonwealth (1981) 146 CLR 559 (allowing government funding of the educational activities of religious schools). The 'right to vote' in $s 41$ guarantees a right to vote only to those who qualified to vote in state elections at the time of federation: $R v$ Pearson; $E x$ parte Sipka (1983) 152 CLR 254. See generally Zines, above $\mathrm{nl}$ at 402-405.

9 George Williams contrasts the interpretation of s80 (in which the 'plain meaning' of the text has been said to preclude a substantive interpretation of 'trial on indictment') with the interpretation of $s 41$ (where historical material was used to limit the apparent plain meaning). He concludes '[i]t is hard to avoid the conclusion that until [the High Court's judgment in Street v Queensland Bar Association in] 1989 judges of the High Court have selectively used whatever tool was available ... to construe sections $41,80,116$ and 117 as empty guarantees'. Williams, above $n 1$ at 128 .

10 See generally Bailey, above $\mathrm{n} 1$ at $84-86$; Williams, above $\mathrm{n} 1$ at $129-154$. Though it should be noted that Cole $v$ Whitfield (1988) 165 CLR 360 narrowed previous interpretations of $\mathrm{s} 92$.

11 See Bailey, above $\mathrm{n} 1$ at 105; Williams, above $\mathrm{n} 1$ at 128, 249-250.

12 See Street $v$ Queensland Bar Association (1989) 168 CLR 461 (hereafter Street), which transformed s117 into a real limitation on government that protects the individual from discrimination based on state residence. 
The first implication, drawn from representative and responsible government, ${ }^{13}$ gives rise to a right of freedom of political communication (a limited kind of free speech right) ${ }^{14}$ and, perhaps, to rights of freedom of movement and association. ${ }^{15}$ Although the court has occasionally been reticent about using the language of rights to describe the freedom of political communication, ${ }^{16}$ the protection conferred by the freedom of political communication fits easily within the concept of a constitutional right. ${ }^{17}$ Indeed the scope of the implied freedom overlaps with (though may be narrower than) the protection conferred by express free speech rights contained in other constitutions. ${ }^{18}$

A second set of constitutional rights is implied from the separation of judicial power. ${ }^{19}$ In general terms, the separation of judicial power requires, first, that the judicial power of the Commonwealth be exercised only by the courts identified in s71 of the Constitution; ${ }^{20}$ and secondly, that courts established by or under the Constitution only exercise the judicial power referred to in Chapter III of the Constitution (together with incidental non-judicial powers). ${ }^{21}$

Those general principles give rise to a wide range of more specific rules, too complex to be summarised here. ${ }^{22}$ These rules can all, in some sense, be

13 In Lange v Australian Broadcasting Corporation (1997) 189 CLR 520 (hereafter Lange), the court emphasised that the freedom of political communication is derived from specific textual provisions implementing certain institutions of representative and responsible government rather than general principles. For a critique of that line of reasoning, see Stone, 'The Limits of Constitutional Text and Structure', above n1.

14 Lange, ibid.

15 The freedoms of movement and association are yet to be determined in any case but have received some judicial recognition. Kruger v Commonwealth of Australia (1997) 190 CLR 1 at 91 (Toohey J), 116 (Gaudron J), 142 (McI lugh J), compare 156 (Gummow J holding that there is no frecdom of association for 'political cultural and familial purposes'). Sec also $R v$ Smithers; Ex parte Benson (1912) 16 CI R 99 at 109-110; Higgins v Commonwealth of Australia (1998) 79 FCR 528 at 535 . On the constitutional right of freedom of association, see Australian Capital Television v Commonwealth (No 2) (1992) 177 CLR 106 (hereafter Australian Capital Television) at 232 (McHugh J); Kruger, id at 91 (Toohey J), 142 (Gaudron J) and Mulholland $v$ Australian Electoral Commission [2004] HCA 41 (hereafter Mulholland) at [113]-[116] (Mcl Iugh J), [148] (Gummow \& I layne JJ with whom I leydon J agreed), [284]-[286] (Kirby J) comparc [334]-[335] (Callinan J).

16 Mulholland, id at [104], [182].

17 Albeit that the freedom is a 'negative' rather than a 'positive' right and therefore operates to prevent interference with political communication rather than facilitate its exercise. In addition the freedom applies 'vertically' against government action (including the judicial enforcement of the common law) rather than 'horizontally' against private action. See Stone, 'Rights, Personal Rights and Freedoms', above $n 1$.

18 On the kinds of communication covered by the frecdom of political communication, sec Stone, 'Rights, Personal Rights and Freedoms', above $\mathrm{n} 1$ at $378-390$; on the level of protection accorded to that communication, see Stone, 'The Limits of Constitutional Text and Structure', above $\mathrm{n} 1$.

19 For an authoritative account see Zines, above $\mathrm{nl}$ at 161-170, 202-212.

20 New South Wales v Commonwealth (Wheat Case) (1915) 20 CLR 54; Waterside Workers Federation of Australia $v J W$ Alexander Ltd (1918) 25 CLR 434.

$21 R v$ Kirby; Ex parte Boilermakers' Society of Australia (1956) 94 CLR 254 affirmed on appeal to the Privy Council in Attorney-General of the Commonwealth of Australia v The Queen (1957) 95 CLR 529.

22 See Zines, above $\mathrm{n} 1$ at $202-212$. 
understood as protecting individual rights because diffusing government power guards against the possibility of abuse of that power. More specifically, the separation of judicial power promotes the independence and impartiality of the judiciary and thus the observance of important aspects of the rule of law. ${ }^{23}$ The implied separation of judicial power also gives rise to some rules that resemble rights commonly found in bills of rights. For example, because the judgment of criminal guilt is regarded an exclusively judicial task, ${ }^{24}$ the High Court has recognised that the Federal Parliament cannot enact a bill of attainder. ${ }^{25}$ In addition, Parliament cannot order detention (at least of a punitive nature) without the intervention of a court. ${ }^{26}$ Finally, there is also a requirement that courts act consistently with judicial process which, though it has not lived up to the hopes of its most vigorous interpreters, has led some commentators to speak of a general right to curial due process. ${ }^{27}$

\section{B. 'Fundamental' Implied Rights}

The Australian Constitution is sometimes understood to contain a third set of rights derived from fundamental doctrines that are said to be assumptions or foundations on which the Constitution is based. One form of this argument has it that the common law contains principles that are so fundamental that they limit parliamentary sovereignty. 28

These rights are much more controversial than the rights implied from text and structure. Rights derived from fundamental doctrines or constitutional

23 Fiona Wheeler, 'Due Process, Chapter III and the New High Court' (2004) 32 Fed LR 205. Blackstone stated that public liberty 'cannot subsist long in any State, unless the administration of common justice be in some degree separated both from the legislative and also from the executive power': see Huddart, Parker and Co Pty Ltd v Moorehead (1909) 8 CLR 330 at 381 (Isaacs J).

24 Chu Kheng Lim v Minister for Immigration (1992) 176 CLR 1 (hereafter Lim) at 27; Nicholas v The Queen (1998) 193 CLR 173 at 186, 208-209, 220. See also Wilsonv Minister for Aboriginal and Torres Strait Islander Affairs (1996) 189 CLR 1 at 11-13.

25 Polyukhovich v Commonwealth of Australia (1991) 172 CLR 501 at 536. For comparable express provisions, see Art I ss 9 and 10 of the Constitution of the United States (prohibiting Bills of Attainder); Canadian Charter of Rights and Freedoms s1 1 (requiring a trial according to law in a fair and public hearing by an independent and impartial tribunal); see also s 25 of the New Zealand Bill of Rights Act (1990) and Art 6 of the European Convention on Human Righis.

$26 \mathrm{Lim}$, above $\mathrm{n} 24$ at 27-28. Those limitations do not, however, preclude the Parliament authorising indefinite administrative detention: Al Kateb v Godwin (2004) 208 ALR 124 (hereafter Al Kateb). Moreover, conditions of immigration detention are not relevant to the validity of that detention: Behrooz $v$ Secretary of the Department of Immigration and Multicultural and Indigenous Affairs (2004) 208 AI,R 271 (hereafter Behrooz).

27 Re Tracey; Ex parte Ryan (1989) 166 CLR 518 at 580: the separation of powers gives rise to 'the Constitution's only general guarantee of due process' (Deane J). See generally, Zines, above $\mathrm{n} 1$ at 202-212; Fiona Wheeler, 'The Doctrine of Separation of Powers and Constitutionally Entrenched Duc Process in Australia' (1997) 23 Mon LR 248.

28 A view defended by TRS Allan, Constitutional Justice (2001). For a critical appraisal see Jeffrey Goldsworthy, 'Homogenizing Constitutions' (2003) 23 Oxford J Legal Studies 483. 
assumptions have only ever been recognised by a minority of the court ${ }^{29}$ and, in some contexts, they have met with explicit rejection. ${ }^{30}$ Moreover, there are clear indications that the present High Court disapproves of this form of reasoning. Recent cases concerning immigration detention, which might have lent themselves to arguments based on fundamental common law rights, ${ }^{31}$ were decided without any reference to the idea. Further, because these rights are derived with little direct appeal to constitutional text, their recognition seems to be precluded by the High Court's recent insistence that constitutional implications must have a firm textual base. $^{32}$

However, these arguments cannot be entirely neglected in a study of Australian constitutional rights. The idea that common law notions might limit parliamentary sovereignty seems to underlie another argument that still influences the High Court. This idea is prominent in the constitutional understandings of Sir Owen Dixon $^{33}$ and finds its most famous expression in his judgment in the Communist Party Case: ${ }^{34}$

[The Australian Constitution] is an instrument framed in accordance with many traditional conceptions, to some of which it gives effect... others of which are simply assumed. Among these I think that it may fairly be said that the rule of law forms an assumption.

No doubt at least partly due to the personal prestige of Sir Owen Dixon, the idea that the 'Rule of Law' is a limiting principle in the Australian Constitution has retained some force, even despite doubts about the more general limiting power of the common law. It reappeared in the joint judgment of Gummow and Hayne JJ in Kartinyeri $v$ Commonwealth, ${ }^{35}$ which suggested that the power in 551 (xxvi) of the Constitution (which confers legislative power with respect to 'the people of any race for whom it is deemed necessary to make special laws') might be limited by Dixon's idea. ${ }^{36}$

29 By Murphy J (see Winterton, above $\mathrm{n} 3$ at 131) and Deane and Toohey JJ (who relied partly on the common law in advancing their argument that the Constitution contained 'a general doctrine of legal equality'): Leeth v Commonwealth (1991) 174 CLR 455 (hereafter Leeth) at 486.

30 Durham Holdings Pty Ltd v State of New South Wales (2001) 205 CLR 399 (rejecting the argument that a common law principle limited the power of a state parliament so that a statute of expropriation must provide for just compensation).

31 In Behrooz, above n26, a detainee charged with 'escaping' from detention asserted that the conditions in which he had been kept were inhuman and degrading. In Al Kateb, above n26, a stateless Palestinian who wished to leave Australia but would not be accepted by any other nation challenged the indefinite nature of his detention. Neither claim succeeded. See above n 26 and accompanying text. For an account of these cases noting the absence of any consideration of fundamental common law rights, see Michael Kirby, 'The Robin Cooke Lecture 2004: Deep Lying Rights - A Constitutional Conversation Continues': <http:/www.hcourt.gov.au/ speeches/kirbyj/kirbyj_25nov04.html\#f107>.

32 Lange, above $\mathrm{n} 13$.

33 See generally Michael Wait, 'The Slumbering Sovereign: Sir Owen Dixon's Common Law Constitution Revisited' (2001) 29 Fed LR 57 at 67-68.

34 Australian Communist Party v Commonwealth (1951) 83 CLR 1 at 193.

35 (1998) 195 CLR 337 (hereafter Kartinyeri). 
The precise content of this 'assumption' is unclear. The 'Rule of Law' is as complex and contested an ideal as there is ${ }^{37}$ and its invocation in Australian constitutional law has been infrequent and sometimes tentative. ${ }^{38}$ However, it is very likely that interpreting the Constitution to contain such an assumption would confer protection like that conferred by constitutional rights in other systems. A procedural conception of the ideal might impose limitations like those imposed by 'due process' guarantees ${ }^{39}$ (thus overlapping with, or perhaps incorporating, implications drawn from the separation of judicial power) and by provisions requiring that limitations on rights be 'prescribed by law'. ${ }^{40} \mathrm{~A}$ 'substantive' conception of the rule of law - which is unlikely though not entirely ruled out on current authority ${ }^{41}$ — could be even more significant. Requiring law to conform to some set of substantive moral criteria may entail protection resembling rights of equality or freedom of speech. ${ }^{42}$

36 Id at 381. Recently, the Court has sought to give some textual basis for this doctrine. See Plaintiff S157/2002 v The Commonwealth (2003) 211 CLR 476 at 513 (Gaudron, McHugh, Gummow, Kirby \& Hayne JJ): 'The provision of the constitutional writs and the conferral upon this Court of an irremovable jurisdiction to issue them to an officer of the Commonwealth [in s75(v)] constitutes a textual reinforcement for what Dixon J said about the significance of the rule of law for the Constitution in Australian Communist Party v The Commonwealth.'

37 Richard Fallon, 'The Rule of Law as a Concept in Constitutional Discourse' (1997) 97 Colum $L \operatorname{Rev} 1$.

38 In Kartinyeri, above $\mathrm{n} 35$ at 381 Gummow and Hayne JJ say only 'the occasion has yet to arise for consideration of all that may follow from Dixon .'s statement'.

39 The rule of law is commonly associated with the idea that the law meets certain procedural requirements that ensure an individual is able to obey it, and that it effectively guides the conduct of citizens, that it is reasonably stable, that legal authority governs the exercise of political power and that it is impartially administered by independent courts: Joseph Raz, The Authority of Law: Essays on Law and Morality (1979) at 212-214. A 'procedural' interpretation of the rule of law would overlap with the guarantee of curial due process derived from the separation of judicial power.

40 Section 1 of the Canadian Charter of Rights and Freedoms provides that 'The Canadian Charter of Rights and Freedoms guarantees the rights and freedoms set out in it subject only to such reasonable limits prescribed by law as can be demonstrably justified in a free and democratic society'. [Emphasis added.] See also European Convention on Human Rights, Arts $10(2)$ and $11(2)$.

41 The judgment of Gummow and Hayne JJ in Kartinyeri, above n35 may even contemplate such an understanding, because they seem to suggest that a law could possibly infringe the rule of law requirement because of its content (the conferral of a racially discriminatory burden). However, there are also indications that point in the other direction. In Re Minister for Immigration and Multicultural Affairs; Ex parte Lam (2003) 214 CLR at 23, McHugh and Gummow JJ stated: 'In Australia, the observance by decision-makers of the limits within which they are constrained by the Constitution and by statutes and subsidiary laws validly made is an aspect of the rule of law under the Constitution. It may be said that the rule of law reflects values concerned in general terms with abuse of power by the executive and legislative branches of government. But it would be going much further to give those values an immediate normative operation in applying the Constitution.' See also Plaintiff S 157/2002 v The Commonwealth, above n36 at [102]-[104]. I am grateful to Graeme Hill for this point.

42 Allan, above $n 28$. 


\section{Rights Protection in Rights-Neutral Contexts}

So far, I have advanced only the well-understood point that rights are protected under the Australian Constitution when there is constitutional language that refers (or is understood to refer) ${ }^{43}$ to a right, and secondly, when some general rightsprotecting principle is given constitutional status (either because it is inferred from the text or, more tentatively, because it is considered to be assumed by the Constitution). But the recognition of express and implied rights does not exhaust the ways in which rights might enter Australian constitutional law. First, these methods might also be combined in quite complex ways. The dissenting justices in Leeth $v$ The Commonwealth, Deane and Toohey JJ, demonstrate the point. ${ }^{44}$ In that case, their Honours derived a right of 'equality before the law' relying both on fundamental principles of common $\mathrm{law}^{45}$ and implications from other features of the Constitution. ${ }^{46}$

In addition, the High Court has incorporated rights into more discrete aspects of its interpretation of the Constitution. The court has sometimes identified limitations that reflect a concern for rights in the course of deciding the extent of a particular power. In this way, considerations of rights may become relevant in what appear to be 'rights-neutral' contexts.

To make this point, I need to make a few preliminary points about constitutional adjudication. Grants of legislative power (like many constitutional provisions) are usually expressed in general terms. Take, by way of illustration, the Commonwealth's power with respect to 'trade and commerce with other countries and among the states ${ }^{47}$ and its power with respect to 'external affairs'. ${ }^{48}$ In the context of individual cases, the courts are faced with very specific questions: can the Commonwealth Parliament use its power over 'trade and commerce with other countries and among the states' to enact a law requiring that interstate traders obtain ministerial approval before exporting a certain good?; ${ }^{49}$ and can the Commonwealth Parliament use its power over 'external affairs' to enact a law that implements obligations assumed under a treaty (the subject of which does not come within any other grant of legislative power) $?^{50}$

One task for a court, therefore, is to transform the Constitution's general commands into rules that are capable of resolving specific disputes. To do this, the courts develop a body of rules or doctrines best known, at least in the Australian

43 The classification of a constitutional provision as a 'right' is sometimes controversial. See below notes 99-101 and accompanying text.

44 Leeth, above n29. I am seeking here to demonstrate possibilities in constitutional interpretation rather than accepted propositions of law.

45 Id at 487.

46 Id at 486 .

47 Section 51 (i).

48 Section 51(xxix).

49 Murphyores Inc Pty Ltdv Commonwealth (1976) 136 CLR 1 (holding that such a law was within the Commonwealth's power with respect to 'trade and commerce with other countries or among the States').

50 See Commonwealih v Tasmania (1983) 158 CLR 1. 
constitutional law, as 'tests'. ${ }^{51}$ Because judges have considerable latitude in the way they formulate these tests, they may develop tests that allow them to take a rights-protective stance.

The rights-protecting potential of these tests is demonstrated by Davis $v$ Commonwealth ${ }^{52}$ and by the judgments of Mason CJ and McHugh $\mathrm{J}$ in Nationwide News $v$ Wills. ${ }^{53}$ In these cases, Commonwealth legislative powers ${ }^{54}$ were held to be subject to limitations that prevented the Commonwealth from circumscribing freedom of expression. In Davis, the court invalidated restrictions on the use of certain expressions (including the use of ' 200 years' in conjunction with ' 1988 ' or ' 88 ') that were imposed as part of the national commemoration of 200 years of white settlement in Australia. ${ }^{55}$ In Nationwide News, some judges used a similar technique to invalidate a law ${ }^{56}$ that prohibited criticism 'calculated...to bring a member of the [Industrial Relations] Commission into disrepute'. 57

These cases are usually taken to demonstrate that common law rights 'enjoy a weak form of constitutional entrenchment' ${ }^{58}$ However, these cases also illustrate the importance, and the rights-protecting potential, of a particular kind of 'test of application' (proportionality) that drew attention to the effect of the law on rights.

For much of its history, the High Court has employed rather deferential tests of application in the interpretation of grants of legislative power. For example, when interpreting incidental powers, ${ }^{59}$ the court showed a high level of deference to the means employed by the Parliament to pursue ends within its power. ${ }^{60}$ But for a

51 For extensive scholarly analysis of these and related kinds of rules as they arise in American constitutional law, see Richard Fallon Jr, 'Supreme Court Foreword: Implementing the Constitution' (1997) 111 Harv LR 54; Lawrence Sager, 'The Strategic Space Between Norms and Rules of Constitutional Law' (1985) 63 Tex LR 959; Mitchell Berman, 'Constitutional Decision Rules' (2004) 90 Va LR 2; David Strauss, 'The Ubiquity of Prophylactic Rules' (1998) 55 UChi LR 190.

52 (1988) 166 CLR 79 (hereafter Davis).

53 (1992) 177 CLR I (hereafter Nationwide News).

54 In Davis, above n52, the so-called 'implied nationhood' power; in Nationwide News $v$ Wills, ibid, the conciliation and arbitration power ( $551(\mathrm{xxxv}))$.

55 Davis, above $\mathrm{n} 52$ at 100 (Mason CJ, Deane \& Gaudron JJ, with whom Wilson, Dawson \& Toohey JJ agreed on this point).

56 Section 299(1)(d)(ii) of the Industrial Relations Act 1988 (Cth).

57 Nationwide News, above n53 at 34 (Mason CJ); see also 102 (McHugh J). Other justices held that the law was contrary to the implied freedom of political communication.

58 Jeffrey Goldsworthy, 'The Constitutional Protection of Rights in Australia' in Greg Craven (ed), Australian Federation, Towards the Second Century (1992) at 151, 157; See also Winterton, above $\mathrm{n} 3$.

59 The Commonwealth Parliament has an express grant of incidental power conferred by s51(xxxix) of the Australian Constitution, which refers to 'matters incidental to the execution of any power vested by this Constitution in the Parliament'. In addition, cach grant of cnumerated power is taken, by virtue of the ordinary rules of construction, to authorise measures that are necessary to effectuate the main purpose of the power: D'Emden v Pedder (1904) 1 CLR 91 at 109; Grannall v Marrickville Margarine Pty Ltd (1955) 93 CLR 55 at 77.

60 See Ilerald \& Weekly Times $v$ Commonwealth (1966) 115 CLR 418 at 437 (Kitto J) for a famous statement of this approach. See generally Zines, above $n 1$ at 47. 
period in the 1990 s, the court sometimes used a test of 'proportionality' 61 to apply closer scrutiny to Commonwealth legislation. Under this test, the court considered whether alternative, less restrictive means could have been used and whether the end pursued by that law was worth the restriction imposed. ${ }^{62}$

In Nationwide News and Davis, the proportionality test drew attention to the adverse consequences of the law - the effect on freedom of expression. ${ }^{63} \mathrm{In}$ Davis, Mason CJ and Deane and Gaudron JJ described the law in question as 'grossly disproportionate to the need to protect the commemoration [of the Bicentenary of European Settlement]'.64 The language of 'proportionality' was also employed in Nationwide News to similar effect. ${ }^{65}$

Thus, these cases demonstrate that rights-promotion need not be pursued only through doctrines understood as 'constitutional rights'. Even when considering the apparently technical question of whether a law was 'with respect to' a nominated head of power, the court had latitude to incorporate rights concerns through closer scrutiny of the means chosen by Parliament to pursue a nominated end. Similar choices arise when framing the test for determining whether a Commonwealth law is contrary to a limitation on power (express or implied), such as the implied freedom of political communication. There is a continuing discussion of the proper test for the application of the freedom of political communication, ${ }^{66}$ including discussion of the appropriate level of deference (if any) that courts should give to legislative judgments. ${ }^{67} \mathrm{~A}$ test that is less deferential to legislative judgment will tend to give more protection to rights. ${ }^{68}$

\section{Existing Constitutional Rights and an Australian Bill of Rights}

I have so far sought to illustrate how the Australian Constitution has been interpreted to protect rights. In the next part of this article, I will identify why the Australian Constitution has proved to be an especially weak mechanism for the protection of rights.

61 Zines, above $\mathrm{n} 1$ at $44-48$.

62 The proportionality test as used by the Supreme Court of Canada and the European Court of Human Rights is usually understood to consist of three inquiries: (1) whether a law exhibits a 'rational connection' to its purported end; (2) the availability of alternative, less drastic means by which that same end could be achieved; and (3) whether the end pursued by that law is worth the restriction or costs imposed. Jeremy Kirk, 'Constitutional Guarantees, Characterisation and the Concept of Proportionality" (1997) 21 MULR 1 at 4-7. But see Leask $v$ Commonwealih of Australia (1996) 187 CLR 579 (hereafter Leask).

63 Davis, above n52 at 99-100.

64 Id at 100 (Mason CJ, Deane \& Gaudron JJ), 116 (Brennan J). For Brennan J it was also relevant that the power was, on his analysis, an incident of the Executive power to 'advance the nation — an essentially facultative function' which made him especially reluctant to allow the creation of offences: at 112-113.

65 Nationwide News, above n53 at 33 (Mason CJ), 101 (McHugh J).

66 See Stone, 'The Limits of Constitutional Text and Structure', above n1; Coleman v Power (2004) 209 ALR at 182, 208, 229 and 233 (hereafter Coleman).

67 For a discussion of this in explicit terms, see Mulholland, above n15 at [237] (Kirby J).

68 As argued in Stone, 'Rights, Personal Rights and Freedoms', above $\mathrm{n} 1$. 


\section{A. The Potential Power of Non-Express Rights}

To make that argument, I will first address a possible suggestion to the contrary. It might be argued that Australia's current system of constitutional rights is an especially powerful method for the protection of rights. Certainly some commentators have considered the existing express and implied rights to be at least functionally equivalent to a bill of rights. Following the early decisions recognising the freedom of political communication, Michael Detmold optimistically heralded the arrival of 'The New Constitutional Law', stating 'we now have everything a written bill of rights could give us' ${ }^{69}$

The argument could perhaps be taken even further. Those who fear that articulating rights in textual form would undesirably limit rights, ${ }^{70}$ or encourage technical legal argument about the meaning of text over substantive consideration of values, ${ }^{71}$ might prefer a system in which rights are implied from constitutional structures or fundamental assumptions. After all, the point of these structural methods of interpretation is that they focus our attention on the nature of the Constitution and the institutions it creates. ${ }^{72}$

Viewed in that light, the interpretive methods just discussed can be viewed as instances of a potentially broader phenomenon. ${ }^{73}$ The method of implication might give rise to a broad range of rights implied from various constitutional structures or perhaps even the nature and existence of the Constitution itself. ${ }^{74}$ The reference to common law rights in Nationwide News and Davis might find analogous applications in the use of international law $^{75}$ or perhaps even by reference to developments in statute law. ${ }^{76}$ Judges may also respond to uncertainty in constitutional meaning by incorporating their own conception of the appropriate protection of rights or by their assessment of community values. ${ }^{77}$

69 Michael Detmold, 'The New Constitutional Law' (1994) 16 Syd LR 228 at 248.

70 George Williams lists this as an argument put against an Australian bill of rights in George Williams, A Bill of Rights For Australia? (2004).

71 A possibility raised by Jercmy Waldron, Law and Disagreement (1999) at 106.

72 Charles Black, Structure and Relationship in Constitutional Law (1969). For Black, the great virtue of the structural method is that 'it frees us to talk sense' when compared with '[t]he textual method [which], in some cases, forces us to blur the focus and talk evasively'. Id at 13.

73 In a recent speech Kirby $J$, above $n 31$, issued a reminder of the continuing significance of implied rights: 'At least in a country such as Australia, without a comprehensive and entrenched Bill of Rights, it is natural that courts should scrutinise cases of apparent or arguable injustice against the criterion of whether the written Constitution permits it - either in its text or in the implications derived from that text or the assumptions upon which it is drawn.'

74 See Detmold, above n69.

75 Prominently (and controversially) Kirby $\mathrm{J}$ interprets the Constitution by reference to international law. Kirby $J$ adopted this approach in his interpretation of the constitutional guarantee of 'just terms' in s51(xxxi) (Newcrest Mining (WA) Ltd v BHP Minerals Ltd \& the Commonwealth (1990) 190 CLR 513 at 657-658), in his interpretation of the Commonwealth's power to make laws with respect to 'the people of any race' (Kartinyeri, above n35 at 417-418) and, most recently, in his interpretation of the Commonwealth's power over aliens and limitations on that power implied from the separation of judicial power (Al Kateb, above $\mathbf{n} 26$ at [150]). 
Detmold's declaration was, to be fair, intended as a statement of constitutional theory rather than a prediction of the direction that the High Court would take. ${ }^{78}$ However, its failure as a matter of prediction points to a deeper problem - the problem of interpretive disagreement. Most of the methods of constitutional interpretation on which Australian constitutional rights rely are contested, either generally or in their specific applications. Disagreement about constitutional rights thus stems from the highly contested nature of constitutional interpretation itself.

Interpretations of the Constitution will be most secure when an interpretation is clearly supported by one or more established methods and is not inconsistent with any of them. Established methods are textual argument, historical (or originalist) argument, argument based on precedent, and implications from the constitutional text and structure. Although there are disagreements about the proper emphasis to be given to these arguments in any given case, it is generally agreed that there is some place in constitutional interpretation for their use. By the same token, however, readings of the Constitution which rely on controversial modes of constitutional interpretation or which seem to run contrary to one of the established modes will be much less secure. The problem for many of the Australian constitutional rights is that there is at least one established form of constitutional argument (usually one based on constitutional text or constitutional history) that undermines them.

\section{B. The Problem of Interpretive Disagreement}

\section{(i) Reliance on a Contested Method of Constitutional Interpretation}

The phenomenon of interpretive disagreement is most obvious in relation to the implication of rights based on fundamental doctrines of the common law or other unexpressed concepts. For this reason perhaps, the implication of such rights has never been fully accepted by the courts, ${ }^{79}$ and the recognition of rights implied in this manner has only ever been sporadic and, except where supported by longstanding precedent, remains tentative. ${ }^{80}$

76 This method is not widely advocated or even discussed. However, in an intriguing passage in Street, above $\mathrm{n} 12$, Gaudron J appears to interpret the Constitution by reference to developments in legislation when, along with other members of the court, she adopted a substantive and more rights-protective interpretation of the concept of discrimination (found in the s117 prohibition on discrimination based on state residence). In reference to the earlier cases on s117, she held at 566 that those cases 'do not reflect recent developments within the field of anti-discrimination law which have led to an understanding that discrimination may be constituted by acts or decisions having a discriminatory effect or disparate impact (indirect discrimination) as well as by acts or decisions based on discriminatory considerations (direct discrimination)'. Her Honour referred to the Sex Discrimination Act 1984 (Cth) s5, the Anti-Discrimination Act 1977 (NSW) s7; and the Equal Opportunity 1ct 1984 (Vic) s17.

77 See John Braithwaite, 'Community Values and Australian Jurisprudence' (1995) 17 Syd LR 351; Wojciech Sadurski, 'Conventional Morality and Judicial Standards' (1987) 73 Va LR 339.

78 Detmold's argument is that the very idea of a constitution brings with it rights at least as extensive as those seen in a typical bill of rights: Detmold, above n69.

79 The method is regarded as relying on weak historical premises and is too imprecise to provide a meaningful limit on government. Winterton, above n3 at 142-143.

80 As is the case with the 'rule of law' assumption recognised in the Communist Party Case, above n34. 
Reservations about this kind of interpretive method have thus prevented the realisation of Michael Detmold's vision of 'The New Constitutional Law' which would recognise extensive implied rights, and in which the interpretation of the Constitution more generally would be infused by a commitment to equality and the rule of law. These reservations have also prevented the general acceptance of Kirby J's anti-originalist ${ }^{81}$ and internationalist ${ }^{82}$ approach to constitutional interpretation. ${ }^{83}$ That approach would allow for much greater protection of rights in the Constitution because it renders irrelevant the framers' decision not to include rights in the Australian Constitution ${ }^{84}$ and provides a mechanism for the incorporation of the growing international law of human rights.

\section{(ii) Accepted Method; Contested Application}

Constitutional interpretation is further complicated by disagreements that arise as to the applications of a given method of interpretation. Thus, even when a method of constitutional interpretation is accepted, particular doctrinal developments are likely to remain disputed. That phenomenon is best illustrated by reference to the implication of the freedom of political communication. The judgments first recognising the freedom of political communication stressed the legitimacy (and prior use) of the method of constitutional implication. ${ }^{85}$ Nonetheless, the implication of a freedom of political communication was controversial, largely because it appeared to run contrary to originalist arguments as to the intention of the framers and because of doubts as to its textual foundation. ${ }^{86}$ Even among those

81 Michael Kirby, 'Constitutional Interpretation and Original Intent: A Form of Ancestor Worship?' (2000) 24 MULR 1.

82 See above $\mathrm{n} 75$.

83 Despite Kirby J's opposition to the originalist method, other members of the court continue to have regard to constitutional history, including the framers' intention, to determine the meaning of the Constitution. Among many cxamples, sec Grain Pool of Western Australia $v$ Commonwealth of Australia (2000) 202 CI R 479 at 492-496, 515, in which a joint judgment of six judges interpreted the Commonwealth's power with respect to 'patents of invention' partly by reference to essential characteristics in 1900 and in which Kirby J declined to consider the historical meaning of the phrase. On these cases see Graeme Hill, "Originalist" "v "Progressive" Interpretations of the Constitution - Does it Matter?'(2000) 11 PLR 159. See also, Singh v The Commonwealth (2004) 209 ALR 355 in which all members of the I ligh Court (including Kirby J) interpret the Commonwealth's power with respect to 'aliens' by reference to the historical understanding of that concept and I eslie 7,ines, "Dead Hands or Living Tree? Stability and Change in Constitutional Law' (2004) 25 Adel LR 3. For a critical assessment of Kirby J's antioriginalism, see Jeffrey Goldsworthy, 'Interpreting the Constitution in its Second Century' (2000) 24 MULR 677. For judicial rejection of Kirby J's approach to international law see $A l$ Kateb, above n26 at 140-144. See generally, Kristen Walker, 'International Law as a Tool of Constitutional Interpretation' (2002) 28 Mon LR 77; Amelia Simpson \& George Williams, 'International Law and Constitutional Interpretation' (2000) 11 PLR 205.

84 For accounts of the framers' attitudes with respect to rights, see Charlesworth, above $\mathrm{n} 1$ at 20 27; see Fnid Campbell, 'Civil Rights in the Australian Constitutional Tradition' in Carl Beck (ed), Law and Justice (1970).

85 Australian Capital Television, above $\mathrm{n} 15$ at 133 (Mason CJ); Nationwide News, above $\mathrm{n} 53$ at 41 (Brennan CJ), 69-70 (Toohey J), 209-210 (Gaudron J).

86 Australian Capital Television, id at 186 (Dawson J). See also, Jeffrey Goldsworthy, 'Constitutional Implications and Freedom of Political Speech: A Reply to Stephen Donaghue' (1997) 32 Mon LR 362 . 
judges who have accepted that some form of implication exists, there are doubts - inspired by originalist and textualist concerns - about some of its applications. In particular, its application to the common law of defamation in Theophanous $v$ The Herald \& Weekly Times ${ }^{87}$ was almost immediately subject to doubt ${ }^{88}$ and soon after revised in Lange $v$ Australian Broadcasting Corporation. ${ }^{89}$

The weakness that arises from this controversy has now been offset by the weight of precedent. The existence of the implied freedom of political communication was affirmed unanimously, though confined, in Lange. By virtue of the weight accorded to that decision, the existence of the implied freedom is probably beyond challenge for the moment. Nonetheless, the controversy surrounding the doctrine and its insecure textual and historical foundations may have ongoing effects. The freedom of political communication still remains the subject of some judicial opposition, ${ }^{90}$ and there may long be a temptation to revisit the foundational question of the doctrine's legitimacy. ${ }^{91}$

In addition, it seems that misgivings about the doctrine's foundation have had a continuing effect on its content. Doubts about the doctrine's textual basis were answered in Lange with an attempt to confine the doctrine to the necessary implications from the text and structure of the Constitution. ${ }^{92}$ However, as I have argued at length elsewhere, ${ }^{93}$ it is not possible to understand or articulate the extent of the freedom of political communication without reference to some ideas or values found outside constitutional text. By discouraging attention to these values, the High Court has deprived itself of the tools it needs to develop the freedom of political communication in a coherent manner. ${ }^{94}$

\section{(iii) Text and Context}

A common thread in this discussion relates to the role of constitutional text. Rights implied from text and structure, rights implied from constitutional assumptions, and rights-sensitive tests of application all lack an obvious textual foundation in

87 (1993) 182 CLR 104.

88 See, McGinty v Western Australia (1995) 186 CLR 140 at 235-236 (McHugh J), 291 (Gummow J).

89 Above $\mathrm{n} 13$ at 566.

90 See Lenah Game Meats v Australian Broadcasting Corporation (2001) 208 CLR 199 at 331 (Callinan J).

91 As has occurred with respect to the implied (or 'unenumerated') constitutional right of privacy and consequent limits on state power to regulate abortion recognised by the United States Supreme Court in Roe v Wade 410 US 113 (1973). Despite widespread doubts about the decision (sec John Hart Ely, 'The Wages of Crying Wolf: A Comment on Roe v. Wade' (1972) 82 Yale LJ 920; Ruth Bader Ginsburg. 'Some Thoughts on Autonomy and Equality in Relation to Roe v Wade' (1985) 63 North Carolina LR 375), Roe v Wade was affirmed (though modified) in Casey v Planned Parenthood 505 US 833 (1992). However, there remains a real possibility that it will one day be overruled. The views of potential Supreme Court Justices on the question are, therefore, closely scrutinised. See, 'Symposium: The Judicial $\Lambda$ ppointments Process" (2001) 10 William and Mary Bill of Rights LJ.

92 Lange, above $n 13$ at 566.

93 Stone, 'The Limits of Constitutional Text and Structure', above n1. For a judicial response, see Coleman, above $\mathrm{n} 66$ at 204-206.

94 For example, the court's commitment to 'text and structure' does not provide an adequate basis for determining the class of communication entitled to protection. On this see Stone, 'Rights, Personal Rights and Freedoms', above $n 1$ at 378-390. 
the Constitution. Reliance on constitutional text is a particularly powerful form of constitutional argument, at least where the text is sufficiently specific to resolve the question at issue. ${ }^{95}$ Thus without clear textual recognition, rights-protective constitutional interpretations are vulnerable to later revision. ${ }^{96}$ It is not surprising therefore to see a judicially created doctrine, like the doctrine of proportionality, revised and considerably confined. ${ }^{97}$

But text alone is also an insecure basis for the recognition of constitutional rights. Where constitutional text is read without reference to its context or its historical understanding, that interpretation is likely to be vulnerable to revision because aspects of context and historical understanding will be advanced as reasons to doubt that interpretation, even if that interpretation could be reconciled with constitutional text. Consider for example, the peculiarly open-textured s 92 . The injunction that 'trade, commerce and intercourse among the States shall be absolutely free' was once read as a guarantee of an individual right to engage in these activities. ${ }^{98}$ However, that interpretation (at least in so far as it applied to inter-state trade and commerce) eventually gave way to an interpretation, informed by the section's history, aimed at preserving free trade among the states. ${ }^{99}$

\section{(iv) Are the Express and Implied Rights really 'Rights'?}

The insufficiency of constitutional text, considered without reference to other sources of constitutional understanding, casts doubt on whether the so-called express rights are properly regarded as 'rights' at all. The chief reason for

95 As I have explained elsewhere, reliance on constitutional text appeals to 'rule of law' values. Constitutional text is an ascertainable and generally applicable source of law and is the result (at least it is often argued) of a legitimate law making process. See Stone, "The I,imits of Constitutional Text and Structure', above $\mathrm{n} 1$ at 706.

96 Michael Dorf has made a similar observation about the use of structural argument in constitutional interpretation: '[i]n our legal culture — by which I mean at least the legal culture of the common law countries and probably something substantially broader - interpretive arguments unmoored from text are always vulnerable to being attacked as illegitimate... structuralism in the absence of clear textual warrant is always vulnerable to retrenchment'. Michael Dorf, 'Interpretive Holism and the Structural Method, or How Charles Black Might Have Thought $\Lambda$ bout Campaign Finance Reform and Congressional Timidity' (2004) 92 Georgetown LR 833 at 834.

97 The High Court has since held that proportionality has a very limited role in determining whether a Commonwealth law is 'with respect to' a (non-purposive) head of legislative power: leask, above $\mathrm{n} 62$. There were differences, however as to how that revision was expressed. Brennan J's approach was to equate the test of proportionality with more deferential (and traditional) tests of application, finding that "[p]roportionality is another expression for "appropriate and adapted"... [s]o used, proportionality has nothing to say about the appropriateness, necessity or desirability of the law to achieve an effect or purpose'. Leask, above $n 62$ at 593 . Dawson $J$, on the other hand, declared that to introduce the concept of proportionality ... is to introduce a concept which is alien to the principles which this court has hitherto applied': at 602.

98 Commonwealth v Bank of New South Wales (1949) 79 CLR 497; Hughes \& Vale Pty Ltd $v$ New South Wales (No l) (1954) 93 CLR 1. For an account of the complex history of $s 92$ and its various interpretations see Zines, above $\mathrm{n} 1$ at 124-135 and Michael Coper, Freedom of Interstate Trade under the Australian Constitution (1983).

99 Cole v Whitfield, above $\mathrm{n} 10$. Zines, above $\mathrm{n} 1$ at 136-143. 
regarding these provisions as 'express rights' is that they appear to resemble rights found in constitutional bills of rights in other systems. ${ }^{100}$ However, despite this superficial resemblance, there are some other matters - some contextual and some historical — that suggest an opposite conclusion. For one thing, these provisions are scattered through a document otherwise concerned with structures of government and the division of power between the central and state governments. Although that is not entirely unprecedented, ${ }^{101}$ their textual manifestation reflects the place they held in the framers' deliberation. At most, rights were an intermittent concern in a task overwhelmed with the more pressing task of forming a federation. ${ }^{102}$

The classification of many constitutional provisions as constitutional rights may therefore be open to challenge by reference to methods of constitutional interpretation that rely on historical meaning. Consider the protection of religion conferred by $\mathrm{s} 116$ of the Constitution. An interpretation informed by the history of that provision (and perhaps also the context of the provision, or at least its 'free exercise' and 'non-establishment' requirements, which is placed in a chapter headed 'The States') might interpret the provision to be aimed only at preserving state independence with respect to the regulation of religion. ${ }^{103}$ On this analysis, s116 would be devoted to dividing power among the states and the Commonwealth, like much of the rest of the Constitution.

Section 80 could be similarly reinterpreted. James Stellios has shown how such an argument could be made in relation to the jury trial requirement of s80, which he characterises as 'an essential element of [the] federal structure'. ${ }^{104} \mathrm{His}$ argument is that 880 operates: to qualify the power of state Parliaments over the constitution of state courts; ${ }^{105}$ to empower a lay panel of a federal court to exercise the judicial power of the Commonwealth (in the form of jury trials); and to ensure that in federal criminal cases, accused persons face a jury drawn from their own

100 Compare for example the text of s116 ('The Commonwealth shall not make any law for establishing any religion, or for imposing any religious observance, or for prohibiting the free exercise of any religion, and no religious test shall be required as a qualification for any office or public trust under the Commonwealth') with the relevant parts of the First Amendment to the Constitution of the United States ("Congress shall make no law respecting an establishment of religion, or prohibiting the free exercise thereof').

101 Consider the 'Bill of Attainder' clauses in Art I ss3 and 10 of the United States Constitution.

102 See Charlesworth, above $n 1$ at 20-27; Campbell, above $n 84$.

103 Such an analysis might rely on constitutional history. Delegates at the drafting Conventions appear to have been concerned that 'without the prohibition, the Commonwealth would have been in a position to regulate Sunday observance throughout Australia... it was clear that the mere prospect, however remote, of a federal government legislating in this area was one which most state representatives desired to avoid.' Campbell, above n84 at 307-308. See also, John Quick \& Robert Randolf Garran, Annotated Constitution of the Australian Commonwealth (1901) at 951 .

104 James Stellios, "Section 80 of the Constitution - "A Bulwark of Liberty" (2005) (1) 27 Syd $L R 113$ (forthcoming).

105 By preventing them from abolishing jury trials when the federal Parliament has provided for a trial by indictment for an offence against Commonwealth law. 
state. Stellios' argument is important because it accepts the (undeniable) point that the reasons given for the current interpretation of s80 are unconvincing, but challenges the idea that a 'rights-promoting' interpretation would be the natural replacement. It remains to be seen whether such arguments are available with respect to other 'express rights', but the argument serves as a reminder that, even in this sphere, a rights-promoting interpretation may not be the only coherent alternative to the current interpretation.

At base, the problem with Australia's constitutional rights is that in most cases, there are interpretive arguments that count against them (as well as some that count in their favour). So, many of the Australian constitutional rights are likely to be mired in controversy not just as to their meaning, but also as to their existence. In this sense then they are a particularly weak form of constitutional rights protection.

\section{Conclusion}

Like most other commentators on the Australian Constitution, I regard it as a weak institution for the protection of rights. In this article, I have located the source of that weakness more precisely in the interpretive controversy that inevitably attends rights-protective readings of a constitution that, in textual and historical terms, is so inhospitable to rights. Having reached that conclusion I will not, however, go on to argue for a constitutional bill of rights. Indeed, I regard the current state of Australia's constitutional rights as largely irrelevant to that question.

That conclusion might not be immediately obvious. At first glance, my argument could make an Australian bill of rights seem more attractive. An express bill of rights would, after all, settle interpretive controversy as to the existence of constitutional rights. An express bill of rights would provide judges with two good arguments for the existence of constitutional rights - constitutional text and a clear expression of 'original' intention. ${ }^{106}$ If the Australian Constitution contained an explicit right of freedom of expression, a right of due process or an equality guarantee, there would be no point to a debate about whether one should be implied from text and structure or in some other manner. Similarly, guarantee of a right to a jury trial (without a requirement for indictment) would end the attempts to derive such a guarantee from s80, and an express freedom of religion (expressed in terms that made it generally applicable) would render irrelevant the limitation of s116 to Commonwealth laws.

The settling of this interpretive controversy, however, does not make the case for an Australian bill of rights. Certainty is an important legal value, but the adoption of a bill of rights would, if anything, make Australian constitutional law more complex and uncertain. The adoption of a bill of rights would settle

106 That is, the enactment of a bill of rights would be taken as an expression of intention (by the framers of that bill of rights and by the people who ratified it) to protect rights. 
interpretive controversy about the existence of rights, but an interpretive controversy about the precise meaning of the rights adopted would remain. ${ }^{107}$

Importantly, that controversy about the meaning of rights would not be reduced by their recognition in constitutional text. The text itself will provide only limited guidance. ${ }^{108}$ Further, though a court interpreting a bill of rights would have various interpretive resources (such as international case law and scholarship on questions of rights), the guidance such resources could provide is also limited.

In each case, these resources are undermined by the prevalence of disagreement about the precise meaning of rights concepts. It is because rights are the subjects of such disagreement that bills of rights are expressed in general terms, leaving disputes about the limits of rights and their competing conceptions unresolved. ${ }^{109}$ That same disagreement about rights would be reflected in other interpretive resources. Consider, for example, the suggestion that ' $[t]$ he social or political background to rights created [through a bill of rights formulated with wide popular involvement] may ... assist the High Court in its role by giving it the context necessary to balance rights against other community interests'. 110 Although the 'social and political background' may illuminate very general points of agreement (as may the text), it is difficult to see how it would yield much information useful in the rather precise process of determining 'the limits of a right'. 111

And as a practical matter, a bill of rights would almost certainly expand the realm of constitutional rights. Therefore, even if (contrary to my earlier argument) a bill of rights could achieve greater certainty about the content of, say, constitutional freedom of expression, a bill of rights would give rise to many controversies surrounding rights that currently do not have constitutional status.

107 In relation to the freedom of expression, I address some of these issues in Stone, 'The Limits of Constitutional Text and Structure', above n1, and Stone, 'Rights, Personal Rights and Freedoms', above $\mathrm{n} 1$.

108 It would, of course, be entirely naïve to suggest otherwise. Although rights can occasionally be expressed in a relatively specific form, most rights are expressed in general terms. Moreover, as Leighton McDonald points out, generality in the expression of rights is inevitable. In a diverse society, it is only because rights concepts are indeterminate (and the terms in which they are expressed consequently general) that a bill of rights can obtain general agreement. Leighton McDonald, 'New Directions in the Australian Bill of Rights Debate' (2004) 12 Public Law 22.

109 Jeremy Waldron, Law and Disagreement (1999) at 220; Andrei Marmor, 'On the Limits of Rights' (1997) 16 Law and Philosophy 1.

110 Williams, above $\mathrm{n} 1$ at 259.

111 Williams admits these resources would not provide the courts with very precise guidelines for the resolution of particular disputes but maintains that they "would assist a court in ascertaining the appropriate limits of a right and where it might draw the line between the judicial and political process'. Williams, above $\mathrm{n} 1$ at 259 . But 'ascertaining the appropriate limits of a right' requires a precise determination of the nature of a right (what activity it covers, how much protection it confers on that activity) and its relative weight with respect to other rights and interests. If 'the social and political background' or 'context' cannot assist with that task then it is difficult to see what it adds to the process of applying rights and in particular how it renders that task more precise than the task of applying implied rights. 
An argument for an Australian bill of rights does, of course, remain. By resolving interpretive disagreement about the existence of rights, an express bill of rights would seriously limit the capacity of a court to eviscerate or completely eradicate those rights. However, the weakness of the existing constitutional rights — including the possibility of their eradication - is only undesirable if stronger constitutional rights are desirable. Thus, we return to that fundamental question: whether constitutional rights are, in the final analysis, to be preferred to other methods of rights protection. 


\section{University Library}

\section{- M M I E E R VA A gateway to Melbourne's research publications}

Minerva Access is the Institutional Repository of The University of Melbourne

Author/s:

Stone, A

Title:

Australia's Constitutional Rights and the Problem of Interpretive Disagreement

Date:

2005-03-01

Citation:

Stone, A. (2005). Australia's Constitutional Rights and the Problem of Interpretive

Disagreement. SYDNEY LAW REVIEW, 27 (1), pp.29-48

Persistent Link:

http://hdl.handle.net/11343/27898 